Knowledge by Ritual 


\section{Journal of Theological Interpretation Supplements MURRAY RAE \\ University of Otago, New Zealand \\ Editor-in-Chief}

1. Thomas Holsinger-Friesen, Irenaeus and Genesis: A Study of Competition in Early Christian Hermeneutics

2. Douglas S. Earl, Reading Joshua as Christian Scripture

3. Joshua N. Moon, Jeremiah's New Covenant: An Augustinian Reading

4. Csilla Saysell, "According to the Law": Reading Ezra 9-10 as Christian Scripture

5. Joshua Marshall Strahan, The Limits of a Text: Luke 23:34a as a Case Study in Theological Interpretation

6. Seth B. Tarrer, Reading with the Faithful: Interpretation of True and False Prophecy in the Book of Jeremiah from Ancient Times to Modern

7. Zoltán S. Schwáb, Toward an Interpretation of the Book of Proverbs: Selfishness and Secularity Reconsidered

8. Steven Joe Koskie, Jr., Reading the Way to Heaven: A Wesleyan Theological Hermeneutic of Scripture

9. Hubert James Keener, A Canonical Exegesis of the Eighth Psalm: YHWH's Maintenance of the Created Order through Divine Intervention

10. Vincent K. H. Ooi, Scripture and Its Readers: Readings of Israel's Story in Nehemiah 9, Ezekiel 20, and Acts 7

11. Andrea D. Saner, "Too Much to Grasp": Exodus 3:13-15 and the Reality of God

12. Jonathan Douglas Hicks, Trinity, Economy, and Scripture: Recovering Didymus the Blind

13. Dru Johnson, Knowledge by Ritual: A Biblical Prolegomenon to Sacramental Theology

14. Ryan S. Peterson, The Imago Dei as Human Identity: A Theological Interpretation

15. Ron Haydon, "Seventy Sevens Are Decreed": A Canonical Approach to Daniel 9:24-27 


\title{
Knowledge by Ritual
}

\author{
A Biblical Prolegomenon to \\ Sacramental Theology
}

DRU JOHNSON

Winona Lake, Indiana

EISENBRAUNS

2016 


\section{Copyright (C) 2016 Eisenbrauns}

All rights reserved.

Printed in the United States of America

www.eisenbrauns.com

\section{Library of Congress Cataloging-in-Publication Data}

Names: Johnson, Dru, author.

Title: Knowledge by ritual : a biblical prolegomenon to sacramental theology / Dru Johnson.

Description: Winona Lake, Indiana : Eisenbrauns, 2016. I Series: Journal of theological interpretation supplements ; 13 I Includes bibliographical references and index. I Description based on print version record and CIP data provided by publisher; resource not viewed.

Identifiers: LCCN 2015043623 (print) I LCCN 2015042029 (ebook) | ISBN 9781575064321 (PDF) I ISBN 9781575064314 (pbk. : alk. paper)

Subjects: LCSH: Sacraments. I Rites and ceremonies. I Knowledge, Theory of (Religion)

Classification: LCC BV800 (print) I LCC BV800 .J59 2016 (ebook) I DDC $264.001-\mathrm{dc} 23$

LC record available at http://lccn.loc.gov/2015043623

The paper used in this publication meets the minimum requirements of the American National Standard for Information Sciences-Permanence of Paper for Printed Library Materials, ANSI Z39.48-1984.@TM 
To my mother and father, Patricia and Kenneth,

who instilled in me a profound reverence for the human body, personal history, and the work of the Divine in the world. 
This page intentionally left blank. 